Open Access

Research Article
Res. Agric. Livest. Fish. Vol. 2, No. 3, December 2015: 427-437

\title{
CORRUPTION AND THE AGRICULTURAL PRODUCTION EFFICIENCY OF THE EUROPEAN COUNTRIES DURING THE RECENT ECONOMIC CRISIS
}

\author{
Mohammad Monirul Hasan ${ }^{1, *}$ and József Tóth ${ }^{2}$ \\ 1Department of Economic and Technological Change, Center for Development Research, \\ University of Bonn, Walter-Flex-Str. 3, D-53113, Germany; ${ }^{2}$ Corvinus University of \\ Budapest, Department of Agriculture Economics and Rural Development, H-1093, \\ Budapest, Fovam ter 8, Hungary
}

*Corresponding author: Mohammad Monirul Hasan, E-mail: mhasan@uni-bonn.de

\section{ARTICLE INFO}

Received

09.10 .2015

Accepted

11.12 .2015

Online

21.12.2015

Key words

Technical efficiency Corruption control Govt. effectiveness Economic crisis Regional disparity European agriculture
This paper examines the association between controls of corruption and the agricultural production efficiency of 23 European Union Member States during the recent economic crisis. Production efficiency, measured in terms of technical efficiency, is the effectiveness of a given set of inputs that is used to produce an output. Owing to climate and geographical location agriculture in European countries is diverse. The economic downturn led by the financial crisis which started in mid-2007, is still prevailing across European countries. Control of corruption along with the existing economic crisis of the member states are affecting agriculture production efficiency. This study used the national level production data for the period of 2003-2009. It shows that the technical efficiency of most Member States have declined over the years and that it was significantly lower in austere economic crisis time 2007-09 than 2003-06 for all countries. It is also found that the declining trend of technical efficiency is significantly lower for central and eastern European countries than for the western European countries. Study finds that the control of corruption in the presence of high government effectiveness, decreases the technical efficiency of agricultural production in the Member States.

To cite this article: Hasan MM and J Tóth, 2015. Corruption and the agricultural production efficiency of the European countries during the recent economic crisis. Res. Agric. Livest. Fish. 2 (3): 427-437.

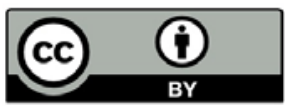

This is an open access article licensed under the terms of the Creative Commons Attribution 4.0 International License

www.agroaid-bd.org/ralf, E-mail: editor.ralf@gmail.com 


\section{INTRODUCTION}

Production efficiency, measured in terms of technical efficiency, is the effectiveness of a given set of inputs that is used to produce an output. A firm is supposed to be technically efficient if the firm produces the maximum output from the minimum quantity of inputs, such as land, labor, capital and technology. Agriculture in European countries is diverse due to climate and geographic locations. Furthermore, some European countries are restricting agricultural production due to market adjustment while some others are trying to produce as much as they can. The economic crisis that started in 2007, and is still ongoing, is spread across Europe and is going to impact the agricultural sector a lot. European Commission estimated that GDP will contract by about $4 \%$ in 2009 and by $0.1 \%$ in 2010, both in the EU-27 and in the Eurozone (EC, 2009). The longer-term consequences on potential output are however less clear. So there is an unclear impact on the overall economy including agricultural production in both the short and the long term. Our aim is to measure how technical efficiency of agriculture is affected by the control of corruption in the presence of government effectiveness in this period of economic crisis especially in 2003-09 and which part of Europe is being challenged by this declining technical efficiency.

The financial crisis has had a large negative impact on potential output in the short term and there is the prospect of a longer period of slow growth which could lead to economic depression (EC, 2009). But, according to literature, it is too soon to draw a complete and strong conclusion about the fate of the economy as a whole. The slow process of industrial restructuring due to credit constraints, the impaired system of capital allocation and structural rigidities can hurt the level and growth rate of Total Factor Productivity (TFP) in the medium to long term by locking up resources in relatively unproductive activities. Agriculture is the most important industry in Europe and the output of agricultural sector is being controlled in so many ways to meet the challenges of lower prices and higher payments to the farmers. But the production efficiency is in question year by year. What is going on in this particular issue? Does control of corruption affect technical efficiency due to economic recession in European Union (EU) Member States? In this paper we observe technical efficiency in recent years. We also use the control of corruption and government effectiveness variables to test whether the technical efficiency changes over. Furthermore we analyze the statistical significance of the changes in the technical efficiencies of the EU Member States during the period 2007-2009 using panel data econometric regression model.

\section{Literature review}

Some authors calculated the technical efficiency in European countries for specific products. Zhu et al. (2008a) calculated technical efficiency during the period 1995-2004 for dairy farms in EU Member States. Carroll et al. (2009) reported that in the period 1996-2006 the technical efficiency changed for several production types in Ireland. Some authors (e.g. Morrison Paul et al., 2000; Brümmer et al., 2006; and Lambarra et al., 2009) compared the impact of policy reform on technical efficiency.

The effect of farm size on technical efficiency is being investigated using various indicators of size as there is no consensus on the best measure for size in agriculture. Total output produced (e.g. Latruffe et al., 2004); utilized agricultural area (e.g. Nasr et al., 1998; Munroe, 2001; Helfand and Levine, 2004; Hadley, 2006; Rios and Shively, 2006; Latruffe et al., 2008a; Carroll et al., 2009); number of cows or pigs (Weersink et al., 1990; Sharma et al., 1999; Brümmer and Loy, 2000; Hadley, 2006; Tonsor and Featherstone, 2009); farm value added (Hallam and Machado, 1996); labour used or assets (e.g. Bojnec and Latruffe, 2007) are all being used as inputs for the technical efficiency score calculation.

To capture the effect of agricultural policy reform on technical efficiency, some authors (e.g. Morrison Paul et al., 2000; Brümmer et al., 2006; Carroll et al., 2009; Lambarra et al., 2009) used year-specific dummy variables to capture policy changes. Several authors, such as Weersink et al. (1990), Hallam and Machado (1996), Sharma et al. (1999), O'Neill and Matthews (2001), Rezitis et al. (2003), Helfand and Levine (2004), Latruffe et al. (2008b), Zhu et al. (2008b), Tonsor and Featherstone (2009) and Bakucs et al. (2010) included location dummies such as state, regional or country level in their regression of farm technical efficiency scores to see the regional disparities. Zhu et al. (2008b) found that being located in Less Favourable Areas (LFA) decreased the technical efficiency of Greek olive farms during the period 1995-2004. The fact that a location 
600 metres above sea level reduced Slovenian farms' technical efficiency in 1995-1996 was shown by Brümmer (2001). Technical efficiency is found consistently negative in most studies such as Giannakas et al. (2001), Rezitis et al. (2003), Hadley (2006), Zhu et al. (2008a), Latruffe et al. (2008b) and Bakucs et al. (2010).

Corruption works to 'grease the economy' in highly regulated and bureaucratic economies. Corruption could increase economics development because illegal practices works as "speed money" could surpass bureaucratic delays which in turn increases government effectiveness (Hasan, A. et al., 2014 and Wei, 1998). Corruption starts working well for the low level of economic development and becomes harmful to growth for the high level of economic settings (Méndez and Sepúlveda, 2006); Neeman et al. (2008); Méon and Weill (2010). In highly regulated countries corruption can increase the enterprise efficiency and productivity. Dreher and Gassebner (2011) found that the existence of a larger number of procedures and higher minimum capital requirements are detrimental to entrepreneurship. So corruption reduces the negative impact of regulations on entrepreneurship in highly regulated economies. Similar results are also found by Leff (1964); Leys (1965); Huntington (1968); Beck and Mahler (1986); Lien (1986) and Vial and Hanoteau (2010), establishing that corruption increases efficiency. So it is more likely that being a country with less and lesser corruption with effective governance may reduce the aggregate technical efficiency of agricultural sector. Government effectiveness is positively associated with technical efficiency scores which is found from analysis of Evans and others done in 2000 (Grigoli, Francesco and Ley, Eduardo, 2012).

Economic recession reduces production-specific organization capital by unsettling normal production, distribution, marketing and inventory strategies which lead to the reduction of production efficiency (Ohanian, 2002). 'Organizational capital' refers to the knowledge firm use to organize production (Prescott and Visscher, 1980). Changes in organizational capital are important for production technology which may fall during Economic depression resulting the reduction of production efficiency (Ohanian, 2002). The reduction of efficiency occurs by chief managers to shift time away from production and into search activities. Reduced amount of managerial labor input to organizing and planning production lowers efficiency. The economic crisis during 2007-09 also has created the same vibration to the agricultural technical efficiency in the European countries.

Economic literatures is focusing on technical efficiency by investigates its nature and the determinants of technical efficiency. Many papers highlighted on the specific country or a product to see the technical efficiency but less focus on the cross country comparison especially in the time of austere economic crisis. Most papers talk about corruption and government effectiveness and also efficiency. But role of control of corruption to agricultural technical efficiency in the presence of high government effectiveness is scant in the literature. Hence it becomes more relevant especially in the context of austere economics crisis of Europe. This paper contributes to the study of how control of corruption is associated with the declining trend of agricultural technical efficiency during the economic crisis time especially in the cross country comparison.

\section{Data}

For our analysis of agriculture productivity we used World Bank data. The aggregate agricultural output and inputs of each EU Member State during the period 2003-2009 were used. There are some limitation of the data usage in the study. The analysis is confined to 2009 due to unavailability of data for the period 20102013. Twenty-three EU Member States were considered because data for some countries of the EU-27 are not available in the World Bank data set. We also incorporated the control of corruption index and government effectiveness index from the World Bank dataset. This gave us a short panel of 7 years and 23 EU Member States. Our dataset was classified into three regional groups, namely western European countries (Austria, Denmark, Finland, France, Germany, Ireland, Luxembourg, Netherlands and Sweden), central and eastern European countries (Bulgaria, Czech Republic, Estonia, Hungary, Latvia, Lithuania, Poland, Romania, Slovakia and Slovenia) and southern European countries (Italy, Malta, Portugal and Spain). In our analysis of technical efficiency we collected the following variables:

- Inputs: Total agricultural land (square kilometer) ; Total agricultural labor (number of agricultural workers); Average fertilizer use (kilogram per hector);

- Output: Aggregate output of agriculture (value added, constant 2000; USD) 
From World Bank dataset we have taken total agricultural land which is measured in square kilometer of European Member States. Agricultural land consist of arable land area under permanent crops and pastures, temporary meadows, land under kitchen garden and land temporary fellow. Abandoned land is excluded. Another factor of production is labor which is measured in agricultural workers has taken into account in this analysis. We could get other factors of production such as capital, entrepreneurship, financial loans and activities etc. but due to data unavailability it was not possible. We used the two governance indicators such as control of corruption and government effectiveness to see the changes in the technical efficiency. Government effectiveness is defined by the perception of the quality of public services, civil service and the degree of its independence from political pressures. It also captures the quality of policy formulation, implementation and the credibility of the government's commitment to such policies. Control of corruption characterizes the perceptions of the extent to which public power is exercised for private gain (including petty and grand forms of corruption) by state bureaucrats (government officials, elites) and private interests. Both of these indicators such as government effectiveness and control of corruption is taken from World Governance Indicators (WGI) 2013 of the World Bank. The World Bank made this index.

\section{METHODOLOGY}

The efficiency was measured using the Data Envelopment Analysis (DEA) method which deals with the frontier analysis of the given data. DEA is a non-parametric technique which makes no assumptions about the form of the production technology. It is a non-stochastic approach and the efficiency of each firm is measured by the distance of its input-output vectors to the frontier. It fits a piece-wise linear frontier using a linear programming technique. In this method we used the input oriented method and constant return to scale. The analysis was carried out in two stages. Firstly we calculated the technical efficiency of the 23 EU Member States for the period 2003-2009, and then we analyzed the association of corruption and governance with technical efficiency for this specified period. . In this second part we used econometric regression for seeing the significant association between corruption and technical efficiency along with regional dummies and time dummies.

Data Envelopment Analysis (DEA)

The mathematical explanation of technical efficiency was first framed by Farrell (1957), who described the efficiency in an input-orientation framework, which is to say in terms of potential input reduction while holding the output level unchanged.

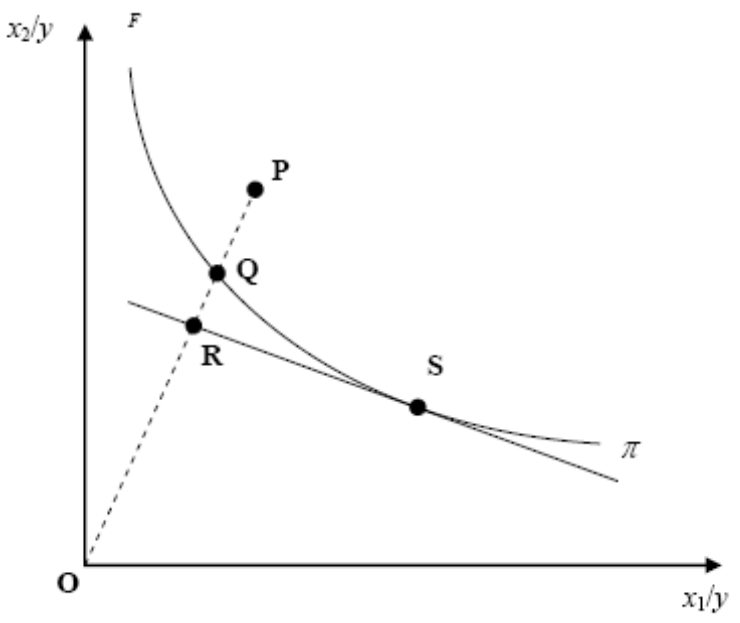

Figure 1: Input-oriented representation of technical efficiency; Source: Farrell (1957). 
Figure 1 portrays the case of a firm producing one output $y$ from two inputs, $x 1$ and $x 2$. The production frontier $\mathrm{MF}$ illustrates the isoquant defining the minimum possible combinations of two inputs that firms can take for producing one unit of output. The frontier confines the observations, in the sense that the observed firms should lie on or beyond it. The point $Q$ is on the frontier but point $P$ is not. $F$ is the technical efficiency frontier which says that any firm lying on the frontier has no possibility of reducing one input without increasing another input, meaning that such a firm is therefore technically efficient. Firm $p$ is not technically efficient although firm $P$ and $Q$ are using the same proportion of inputs shown by the constant ratio ray OP. $P$ could reduce both inputs by $P Q$ and still can produce the same level of output. Proportionally the potential input reduction is:

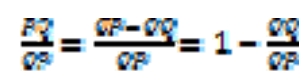

The technical efficiency of firm $P$ is defined by:

$$
T E=\frac{Q Q}{Q F}
$$

The measure of TE is bounded by minimum value 0 and maximum value of 1 which represent $100 \%$ or fully technically efficient where the potential input requirement is zero. Charnes et al. (1978) introduced the most popular method of DEA analysis with multiple input and outputs using linear programming technology. DEA is a simple and sophisticated tool to get consistent estimates of changes in technical efficiency even in the presence of noise. Evidences (Kloss and Petrick, 2014) showed that the assumption of constant technical returns to scale is confirmed. Under the Constant Return to Scale (CRS) assumption, the technical efficiency score, $\theta$ for the $i$-th firm in the input-orientation framework brings the solution for the following linear programming model (Coelli et al., 2005):

$$
\begin{aligned}
& m r_{G,} \theta_{l} \\
& \text { St }-q_{l}+q_{\lambda} \geq 0 . \\
& \sigma x_{L}-x \lambda \geq 0 .
\end{aligned}
$$

$$
\lambda \geq 0 \text {. }
$$

Assuming $\mathrm{K}$ inputs, $\mathrm{M}$ outputs and I number of firms, we can say that $\mathrm{X}_{i}$ is the $\mathrm{K} \times 1$ vector of inputs of $\mathrm{i}$-th firm, and qi is the $M \times 1$ vector of outputs of $i$-th firm. $X$ is a $K \times I$ input matrix, $Q$ is an $M \times \mid$ output matrix. $\theta$ is a scalar (=TE), $\lambda$ is a $1 \times 1$ vector of constants.

\section{Panel data regression: Random Effect Tobit model}

After calculating the technical efficiency score of $23 \mathrm{EU}$ Member States in different years, we sought to analyse the pattern of these efficiency scores. We chose the random effect tobit regression model because out data is truncated between 0 and 1 with panel setting. To justify the use of the fixed effect or the random effect model, we used the Hausman (1978) test. This shows that the probability of chi-square value is greater than 0.05 which prescribes to use the random effect model. The Random effect assumes that the entity's error term is not correlated with the predictors which allows for time-invariant variables to play a role as explanatory variables. In equation, it can be described as:

$$
Y_{\tilde{n}}=\beta x_{\tilde{t}}+v_{i}+z_{\tilde{t}}
$$

\section{The regression model}

The regression model can be simply described as:

$$
T E_{n}=\beta C E_{n}+\gamma C C_{n t}+d T_{n}+\varphi R_{n}+v_{i}+z_{n}
$$

Where TE represents the technical efficiency of country $i$ in time $t, \beta$ represents the coefficient of governance effectiveness, $V$ represents the coefficient of control of corruption. $T$ denotes the time dummies of each country of a specific year and $R$ represents the regional dummies of the specific region. 


\section{DISCUSSION}

The aggregate output of agriculture shows an increasing pattern from 2005 to 2009 (Figure 2). But this increased production value might be due to increased input use. Here, it is observed that some EU Member States experienced declining technical efficiency scores over time, especially in the period 2007-2009. Many factors could contribute to this decline such as government policies including the economic crisis. In the regression result we tried to capture this hypothesis.

EU Member States such as France, Italy, Netherlands and Malta could consistently maintain their technical efficiency scores at the highest level, i.e. 1 (Table 1). This means that in our analysis these countries are fully efficient in production. On the other hand, other EU Member States show a volatile trend of technical efficiency over time which means that they might using high rates of inputs to produce the same level of output. We need to test this hypothesis. The changes in the technical efficiency in 2003-2009 are mostly found in the member states like Denmark, Hungary, Ireland, Luxemburg, Poland, and Romania. Other member states also follow the same trend. In 2003, Denmark had Technical efficiency score 1 but it fails to keep it in the later stages (Table 1).

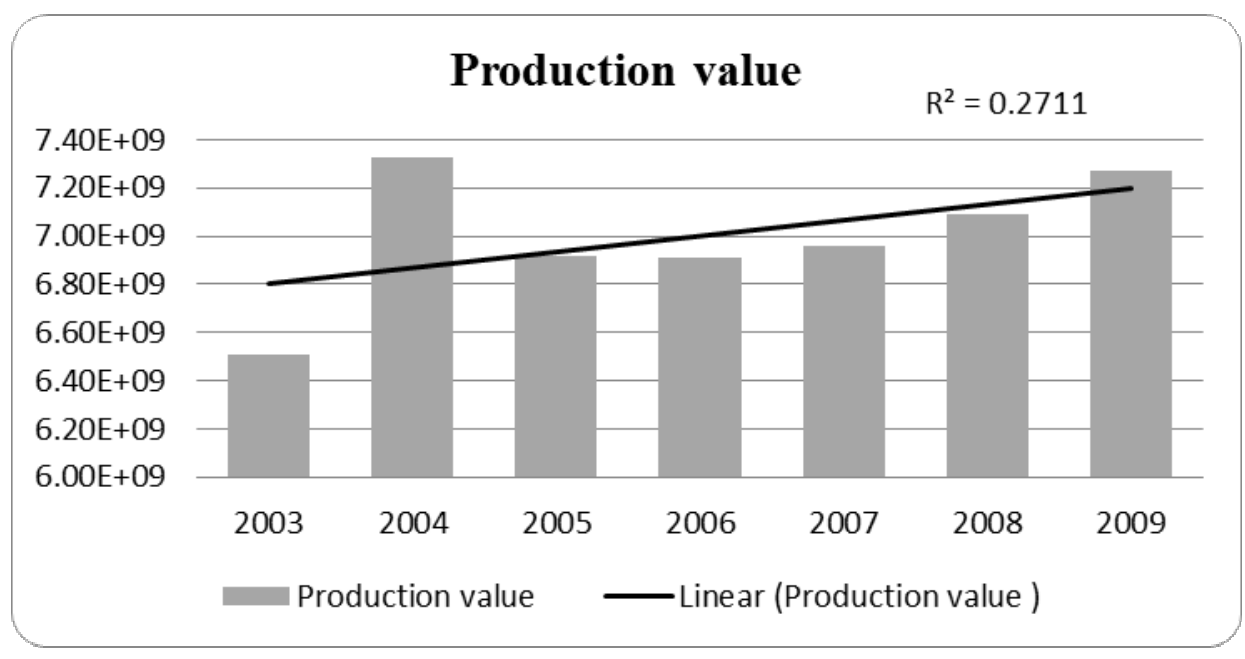

Figure 2. Aggregate output of agriculture (value added, constant 2000; USD); Source: Authors' calculation

EU Member States such as Denmark, Finland, France, Germany, Italy, Malta, Netherlands, Romania, Slovenia, Spain and Sweden could consistently maintain their technical efficiency scores at the highest level, which is almost more than 0.75 (Table 1). This means that in our analysis these countries are efficient in production. On the other hand, other EU Member States such as Estonia, Latvia and Lithuania have technical efficiency score almost below 0.2 which is also lower than other Central and East European member states such as Bulgaria, Czech Republic and Hungary. There are 4 member states like Luxembourg, Poland, Portugal and Slovakia have technical efficiency in between 0.3 to 0.5 .

The technical efficiency of most countries in our study is volatile. There is no specific pattern by bare observation. The economic crisis began in the USA and spread throughout Europe very quickly in this period 2007-09. The financial crises led to liquidity constraints and also to economic recession. The European Commission sought to increase the output and make necessary steps to keep robust agriculture production. The financial crisis can be observed also in our analysis by assuming that technical efficiency will fall significantly in 2007-2009 in all countries. This analysis can be seen in the econometrics panel regression part of our study. 


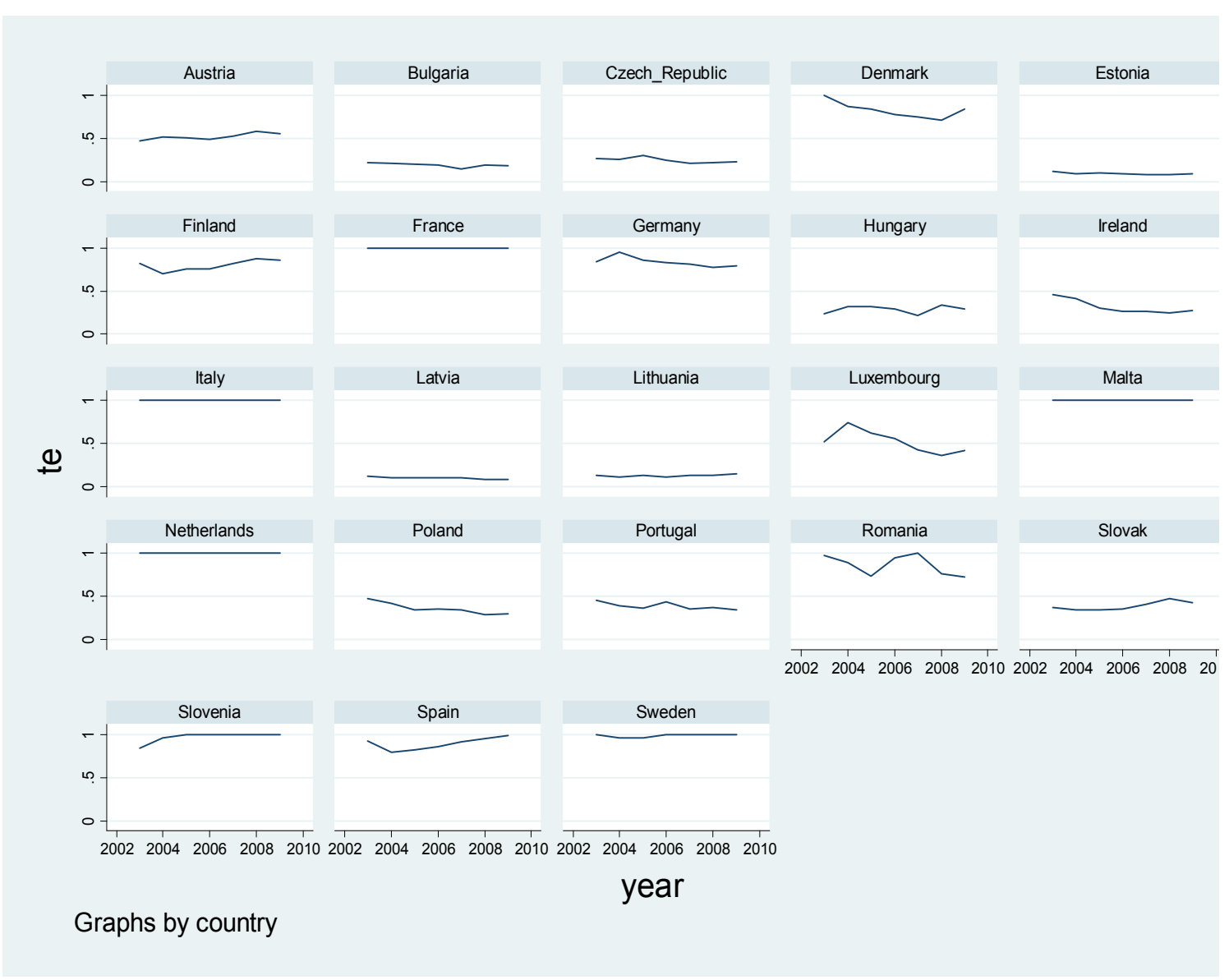

Figure 3. The technical efficiency score of 23 EU Member States, 2003-2009; Source: Authors' calculation

\section{Econometric analysis}

In our random effect tobit regression model (Table 2) we assumed that the economic crisis of the period 2007-2009 had a negative effect on the technical efficiency score of the EU Member States. When we analysed the model the results were significant. In our strongly balanced panel data of technical efficiency, we regressed the variable technical efficiency over all year dummies, government effectiveness, control of corruption and also on the regional dummies of the three regions, western European countries, central and eastern European countries, and southern European countries. After the random effect regression analysis, it is found that the period 2007-2009 gave significant result in the reduction of technical efficiency of all 23 EU Member States in the study (Table 2). In the period 2007-09 the technical efficiency of the countries declined significantly with $5 \%$ level of significance.

In the regional dummies it was found that the technical efficiency of the central and eastern European country declined significantly $(1 \%$ level) in all years whereas the decline in the western European countries was not statistically significant (Table 2). That means that the central and eastern European countries is being less efficient.

In 2007 , the technical efficiency score was significantly reduced by 0.037 , followed by reductions of around 0.042 in 2008 and 0.039 in 2009. In a central and eastern European country the technical efficiency declined by 0.527 units. Although Western Europe also has an increased value it is not statistically significant in our analysis (Table 2).

Although government effectiveness is not significant, the control of corruption is highly significant at the $1 \%$ level (Table 2). This implies that if control of corruption increases by 1 per cent then the technical efficiency is 
likely to decline by 0.12 . May be there are some other factors that work for this relationship but our present data doesn't allow us to investigate the causality how control of corruption affect technical efficiency. But it gives us the sign of negative association which in a sense supports the 'grease the wheel' hypothesis which is, if a country increases the control of corruption with high government effectiveness, the technical efficiency of agricultural production is likely to decrease.

Table 1. The technical efficiency score of 23 EU Member States, 2003-2009.

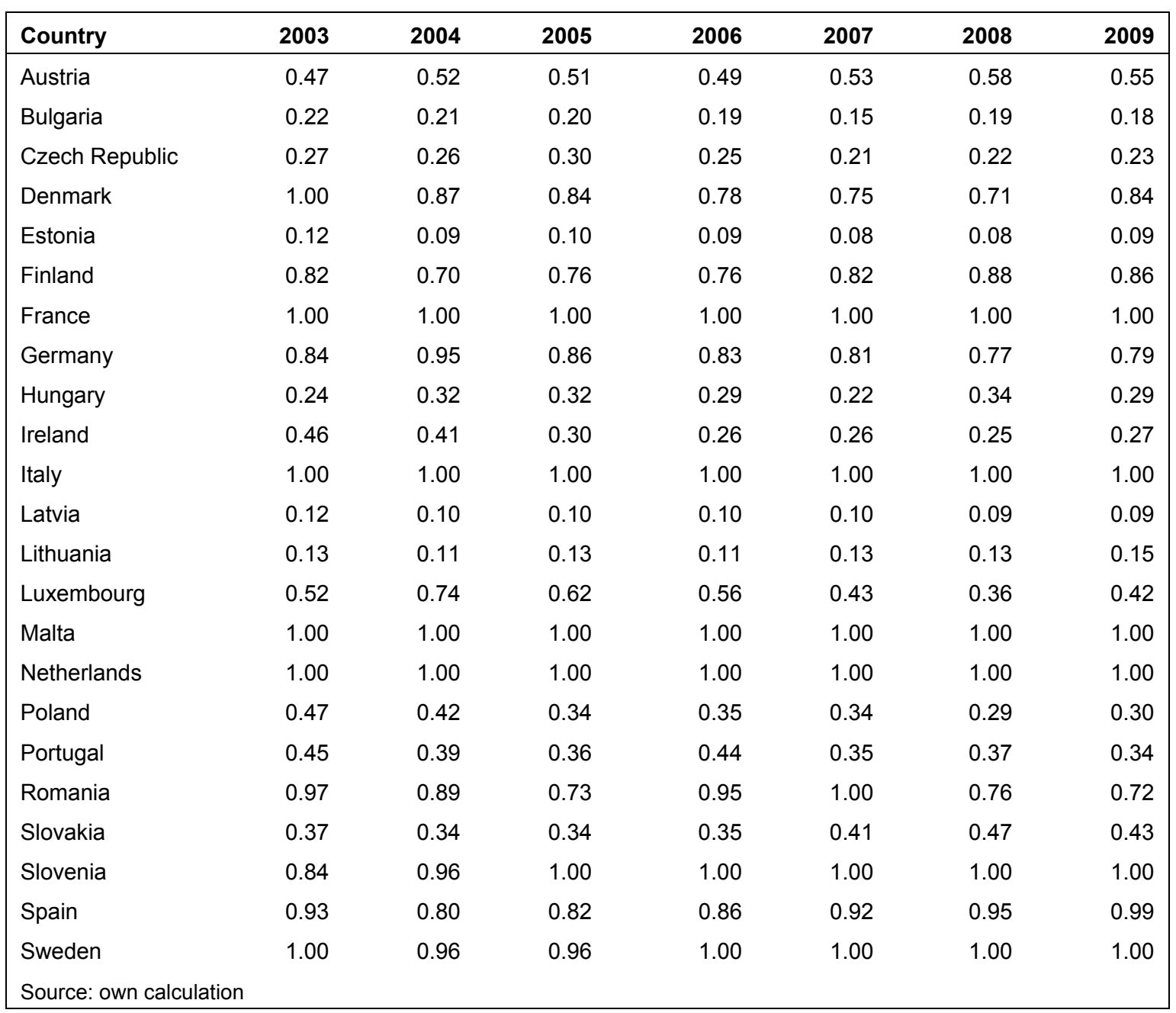

\section{CONCLUSION}

The technical efficiency of many European countries or member states has declined over the period 20032009 and it is significantly lower in 2007-2009. Most countries of Europe show this tends with some exceptions. Some countries are having trend of stagnant for years and some are even better. However, to find the relationship of control of corruption with this technical efficiency scores we find that control of corruption is negatively associated with the technical efficiency score. Government effectiveness is also negatively associated but it is not significant in our analysis. We added other control variables such as the year dummies and the regional dummies to see the robustness of our results and we have found that control of corruption still significantly impacting the technical efficiency. We have also noticed that in the regression results technical efficiency is significantly lower in the years of 2007-09which signifies the austere economic crisis in Europe. So we can say that economic crisis is also impacting technical efficiency negatively although the impact is less than $10 \%$ reduction of technical efficiency. The central and eastern European countries are becoming less efficient than the western European countries according to the regression model result. 
Technical efficiency of central and eastern European countries is reduced by 0.52 point which is significant at $1 \%$ level. So central and eastern European countries are facing hardship of technical efficiency loss especially in the time of austere economic crisis for the agricultural production.

The result in this paper shows basically the association among these variables. Other factors related to productivity also affect the efficiency which cannot be observed from this paper due to data limitation and also methodological stringency. Other methodologies could establish the causality among these variables and establish the relationships. However, this paper acknowledges these limitation invites more research on impact assessment. The produced results in this paper is robust and justified with panel data regression model which clearly reveals the association of the variables with the technical efficiency of the agriculture production in Europe.

Table 2. Random effect tobit model regression analysis of panel data

\begin{tabular}{|lll|}
\hline Dependent variable: & Co-efficient & Standard error \\
Technical Efficiency score & & 0.045 \\
\hline Control of Corruption & $-0.123^{* * *}$ & 0.037 \\
Government Effectiveness & -0.018 & 0.016 \\
Year 2004 & -0.008 & 0.016 \\
Year 2005 & -0.033 & 0.017 \\
Year 2006 & -0.026 & 0.017 \\
Year 2007 & $-0.037^{* *}$ & 0.017 \\
Year 2008 & $-0.042^{* *}$ & 0.016 \\
Year 2009 & $-0.039^{* *}$ & 0.162 \\
central and eastern Europe & $-0.527^{* * *}$ & 0.170 \\
western Europe & 0.091 & \\
Observation & 161 & \\
Number of countries & 23 & \\
Wald chi2(10) & 30.81 & \\
Prob> chi2 & $0.0006^{* * *}$ & \\
Integration points & 12 & 0.040 \\
rho & 0.960398 & \\
/sigma_u & $0.27^{* * *}$ & \\
/sigma_e & $0.05^{* * *}$ & \\
note: ${ }^{* * *} p<0.01,{ }^{* *} p<0.05,{ }^{*} p<0.1$ & & \\
Source: own calculation & & \\
\hline
\end{tabular}

\section{ACKNOWLEDGMENTS}

The authors acknowledge the comments of Professor Imre Ferto and Dr. Tamas Mizik from Corvinus University of Budapest when the paper was presented in the conference of Hungarian Association of Agriculture Economics organized by Corvinus University of Budapest, May 3, 2013. The authors are indebted to the comments received from the NJF Seminar 467, Economic framework conditions, productivity and competitiveness of Nordic and Baltic agriculture and food industries, 12-13 February 2014, Tartu, Estonia. The authors acknowledge the financial support of the Hungarian Scientific Research Fund (OTKA, K 84327) 'Integration of small farms into the modern food chain'. 


\section{CONFLICTS OF INTEREST}

The authors declare that there is no conflict of interest regarding the publication of this paper.

\section{REFERENCES}

1. EC, 2009. Impact of the current economic and financial crisis on potential output. Occasional Papers No. 49. Brussel: European Commission.

2. Zhu X, Demeter R and Oude Lansink A, 2008a. Competitiveness of Dairy Farms in Three Countries: The Role of CAP Subsidies, Paper presented at the 12th EAAE Congress, Gent, Belgium.

3. Carroll J, Greene S, O'Donoghue C, Newman C and F Thorne, 2009. Productivity and the Determinants of Efficiency in Irish Agriculture (1996-2006). Paper presented at the 83rd AES Conference, Dublin, Ireland.

4. Morrison Paul C, Johnston W and G Frengley, 2000a. Efficiency of New Zealand sheep and beef farming: The impact of regulatory reform. The Review of Economics and Statistics, 82: 325-337.

5. Brümmer B, Glauben $\mathrm{T}$ and $\mathrm{W}$ Lu, 2006. Policy reform and productivity change in Chinese agriculture: A distance function approach. Journal of Development Economics, 81: 61-79.

6. Lambarra F, Stefanou S, Sarra T and J Gil, 2009. The impact of the 1999 CAP reforms on the efficiency of the COP sector in Spain. Agricultural Economics, 40: 355-364.

7. Latruffe L, Balcombe K, Davidova S and K Zawalinska, 2004. Determinants of technical efficiency of crop and livestock farms in Poland. Applied Economics, 36: 1255-1263.

8. Nasr R, Barry P and P Ellinger, 1998. Financial structure and efficiency of grain farms. Agricultural Finance Review, 58: 33-48.

9. Munroe D, 2001. Economic efficiency in Polish peasant farming: An international perspective. Regional Studies, 35: 461-471.

10. Helfand $S$ and $E$ Levine, 2004. Farm size and the determinants of productive efficiency in the Brazilian Center-West. Agricultural Economics, 31: 241-249.

11. Hadley D, 2006. Efficiency and Productivity at the Farm Level in England and Wales 1982 to 2002, Final Report to Defra. London: Defra.

12. Rios A and G Shively, 2006. Farm size and nonparametric efficiency measurements for coffee farms in Vietnam. Forests, Trees, and Livelihoods, 16: 397-412.

13. Latruffe L, Balcombe K and S Davidova, 2008a. Productivity change in Polish agriculture: An application of a bootstrap procedure to Malmquist indices. Post-Communist Economies, 20: 449-460.

14. Weersink A, Turney C and A Godah, 1990. Decomposition measures for technical efficiency for Ontario dairy farms. Canadian Journal of Agricultural Economics, 38: 439-456.

15. Sharma K, Leung $P$ and $H$ Zaleski, 1999. Technical, allocative and economic efficiencies in swine production in Hawaii: A comparison of parametric and nonparametric approaches. Agricultural Economics, 20: 23-35.

16. Brümmer B and Loy J P, 2000. The technical efficiency impact of farm credit programmes: A case study in Northern Germany. Journal of Agricultural Economics, 51: 405-418.

17. Tonsor $G$ and A Featherstone, 2009. Production efficiency of specialized swine producers. Review of Agricultural Economics, 31: 493-510.

18. Hallam D and D Machado, 1996. Efficiency analysis with panel data: A study of Portuguese dairy farms. European Review of Agricultural Economics, 23: 79-93.

19. Bojnec $S$ and L Latruffe, 2007. Farm Size and Efficiency: The Case of Slovenia. Paper presented at the 100th seminar of the EAAE, 'Development of Agriculture and Rural Areas in Central and Eastern Europe. Novi Sad, Serbia.

20. O'Neill S and A Matthews, 2001. Technical efficiency in Irish agriculture. The Economic and Social Review, 32: 263-284.

21. Rezitis A, Tsiboukas $K$ and S Tsoukalas, 2003. Investigation of factors influencing the technical efficiency of agricultural producers participating in farm credit programs: The case of Greece. Journal of Agricultural and Applied Economics, 35: 529-541. 
22. Latruffe L, Davidova S and K Balcombe, 2008b. Application of a double bootstrap to the investigation of determinants of technical efficiency of farms in Central Europe. Journal of Productivity Analysis, 29: 183-191.

23. Zhu X, Karagiannis $G$ and A Oude Lansink, 2008b. Analysing the Impact of Direct Subsidies on the Performance of the Greek Olive Farms with a Non-Monotonic Efficiency Effects Model. Paper presented at the 12th EAAE Congress, Gent, Belgium.

24. Bakucs L, Latruffe L, Fertö I and J Fogarasi, 2010. Impact of EU accession on farms' technical efficiency in Hungary. Post-Communist Economies, 22: 165-175.

25. Brümmer B, 2001. Estimating confidence intervals for technical efficiency: The case of private farms in Slovenia. European Review of Agricultural Economics, 28: 285-306.

26. Giannakas K, Schoney R and V Tzouvelekas, 2001. Technical efficiency, technological change and output growth of wheat farms in Saskatchewan. Canadian Journal of Agricultural Economics, 49: 135-152.

27. Latruffe L, Guyomard H, and C Mouël, 2009. The role of public subsidies on farms' managerial efficiency: An application of a five-stage approach to France. INRA- LERECO, Working Paper SMART - LERECO No. 09-05.

28. Dreher A and M Gassebner, 2011. Greasing the wheels?-The impact of regulations and corruption on firm entry. Public Choice, 155: 413-432.

29. Leff $\mathrm{NH}$, 1964. Economic development through bureaucratic corruption. American Behavioral Scientist, 8: 8-14.

30. Leys C, 1965. What is the problem about corruption? Journal of Modern African Studies, 3: 215-230.

31. Huntington SP, 1968. Political order in changing societies. New Haven CT: Yale University Press.

32. Beck PJ and MW Mahler, 1986. A comparison of bribery and bidding in thin markets. Economics Letters, 20: 1-5.

33. Lien DHD, 1986. A note on competitive bribery games. Economics Letters, 22: 337-341.

34. Vial V and $\mathrm{J}$ Hanoteau, 2010. Corruption, manufacturing plant growth and the Asian paradox: Indonesian evidence. World Development, 38: 693-705.

35. Farrell MJ, 1957. The Measurement of Productive Efficiency. Journal of the Royal Statistical Society, Series A (General), 120: 253-290.

36. Charnes A, Cooper W W and E Rhodes, 1978. Measuring the efficiency of decision making units. European Journal of Operational Research, 2: 429-444.

37. Coelli TJ, Rao DSP, O"Donnell C J and G E Battese, 2005. An introduction to Efficiency and productivity analysis. Springer, USA.

38. Morrison Paul C, 2000b. Modeling and measuring productivity in the agri-food sector: Trends, causes and effects. Canadian Journal of Agricultural Economics, 48: 217-240.

39. Hausman J A, 1978. Specification tests in econometrics. Econometrica, 46: 1251-1271

40. Ohanian, Lee E, 2002. Why did productivity fall so much during the great depression? Quarterly Review, 26(2). Federal Reserve Bank of Minneapolis, ISSN 0271-5287.

41. Prescott Edward C and Visscher Michael, 1980. Organizational capital. Journal of Political Economy, 88(June): 446-61.

42. Hasan Ayaydın and Pınar Hayaloglu, 2014. The effect of corruption on firm growth: evidence from firms in Turkey. Asian Economic and Financial Review, 4: 607-624.

43. Méndez $F$ and $F$ Sepúlveda, 2006. Corruption, growth and political regimes: Cross country evidence. European Journal of Political Economy, 22: 82-98.

44. Méon $P$ and L Weill, 2010. Is corruption an efficient grease? World Development, 38: 244-259.

45. Neeman Z, D Paserman and A Simhon 2008. Corruption and openness. The B.E. Journal of Economic Analysis \& Policy, 8: 1-38.

46. Wei SJ, 1998. Foreign, quasi-foreign, and false-foreign direct investment in China, Ninth East Asian Seminars On Economics, June 25-27, 239 - 265, Osaka, Japan.

47. Grigoli Francesco and Ley Eduardo, 2012. Quality of Government and Living Standards: Adjusting for the Efficiency of Public Spending. IMF working paper 12/182.

48. Kloss $M$ and $M$ Petrick, 2014. The productivity of family and hired labor in EU arable farming. GEWISOLA 2014. Göttingen, 17.-19. September 2014. 